\title{
The dietary regulations in Deuteronomy 14 within its literary context ${ }^{1}$
}

\author{
P M Venter \\ Department of Old Testament Studies \\ University of Pretoria
}

\begin{abstract}
A structural analysis of Deuteronomy 14:1-21 indicates a well planned composition. A comparison with the same set of dietary regulations in Leviticus 11:220 indicates a process of literary growth in the Deuteronomy composition. An original list of land animals was extended into a literary unit on dietary regulations. A technique of inclusio was used in different literary layers to form this unit and to include it in the Deuteronomic Code and eventually in the Pentateuch. Different theories on Pentateuchal growth are considered so as to understand the ethical meaning of these dietary regulations within this larger literary framework.
\end{abstract}

\section{INTRODUCTION}

Dietary regulations have an effect on a person's daily life. The dietary rules in Deuteronomy 14:1-20 form part of the ethics of Deuteronomy. To understand their meaning requires a reading of the regulations within the context of Deuteronomy's theology and its ethical implications.

A point of departure for the study of these rules can be found by comparing the dietary regulations in Deuteronomy with the almost identical list in Leviticus 11:2-20. Although these lists are almost similar, they are found in two different literary contexts, giving different meanings to them. A comparison invites both synchronic and diachronic investigation. On a synchronic level, the meaning of each list is defined by the specific

\footnotetext{
${ }^{1}$ This paper was read at the 2002 PROPENT Congress for the advancement of Pentateuch studies in South Africa at Hammanskraal from August 30 to September 02, 2002. The theme of the Congress was "Deuteronomy and Ethics".
} 
literary context in which it is found. On a diachronic level, the two lists appear in two different books, each representing a different literary history. The obvious question that comes to mind is whether the Deuteronomy list was borrowed from Leviticus, or vice versa? Or, could it be that both made use of an existing list of dietary rules which was applied in different ways in the separate books? These questions call for an investigation into the literary history of the books concerned and will eventually lead to the field of Pentateuch studies, with its different theories on the origin and growth of the first five books of the Bible. The aim of this paper is to investigate the dietary regulations in Deuteronomy 14:3-21 synchronically, as well as diachronically against a background of historical research.

\section{THE STRUCTURE OF DEUTERONOMY 14:4-20}

The lists in Deuteronomy 14:4-20 and Leviticus 11:2b-23 both have three sections. They are arranged according to the categories of animals living on land (Dt 14:4-8; Lv 11:2b8), water animals (Dt 14:9-10; Lv 11:9-12) and animals living in the air (Dt 14:11-20; Lv 11:13-23). Von Rad (1966:100) described the list in Deuteronomy 14 as "somewhat heterogenous in form" and revealing a "not uncomplicated construction". A pattern is however visible in both collections insofar as both show a pattern of alternation between prohibitions and rules of consent. The pattern in Deuteronomy is however not totally identical to the pattern found in Leviticus. The Deuteronomy 14:4-20 pattern can be depicted as follows: 


\begin{tabular}{|c|c|}
\hline \multicolumn{2}{|l|}{ DEUTERONOMY 14:4-20 } \\
\hline 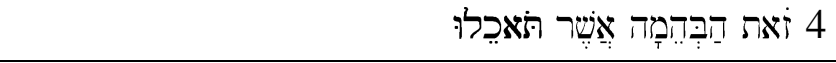 & Consent [ANIMALS ON LAND] \\
\hline 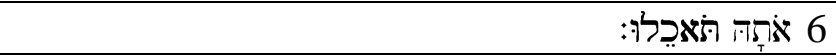 & Consent \\
\hline 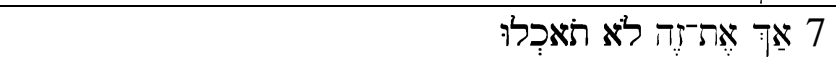 & Prohibition \\
\hline 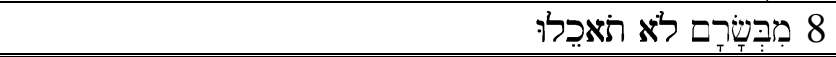 & Prohibition \\
\hline 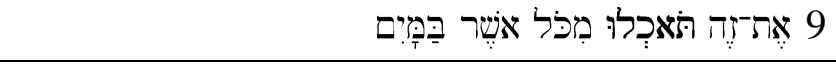 & Consent [ANIMALS IN WATER] \\
\hline 9 תזאכֵלוּ: & Consent \\
\hline 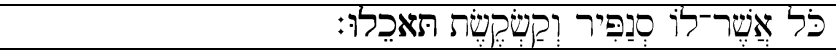 & Consent \\
\hline 10 לא תאכֵלוּ & Prohibition \\
\hline 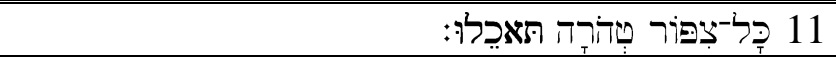 & Consent [BIRDS] \\
\hline 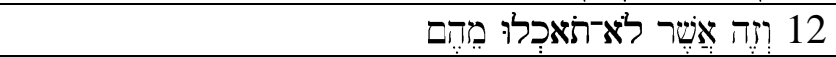 & Prohibition \\
\hline 19 לא יאיכלוּ: & Prohibition \\
\hline 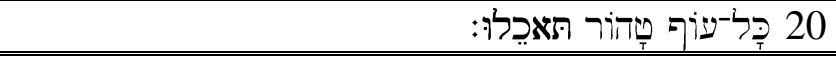 & Consent \\
\hline
\end{tabular}

While the pattern of alternation between prohibition and consent is identical to that of Leviticus in the first two sections dealing with land and water animals, it differs in the third category dealing with animals in the air. An inclusio is found in this instance (Consent-Prohibition-Prohibition-Consent) which differs from Leviticus 11:13-23's Prohibition-Consent-Consent. The motive clause טמקא הוּא לְֶָ is used in both its singular and plural form throughout Deuteronomy 14:4-20. In Leviticus 11:2b-23, it is used four times in the category of land animals ( $\operatorname{Lv} 11: 2 b-8)$, against the two times used in the same לְֶָ category in Deuteronomy 14:4-8. In the other two categories in Leviticus, the clause or variants thereof, are used in the motivational clause. It is also remarkable that 14 animals are listed in the first category (Land animals Deuteronomy 14:4-8), while the joint total for the other two categories is 21 (cf Labuschagne 1990:60).

Another indication of the purposeful structure of Deuteronomy 14:4-20 is found in the near balance between the prohibitions ( 5 times "you shall not eat") and the consents with regard to what Israel was allowed to eat (seven times "you are allowed to eat"). A pattern is also found in the use of the definite article אֶ. While it is used in Lev 11:13-21 with the names of 19 of the 20 birds, in Deuteronomy it is only used in ten of the cases, thereby again creating some balanced structure (cf Moran 1966:273-275). Although the passage contains Numeruswechsel, no pattern is formed by the alternating singular and plural and no specific function can be indicated. 
These observations confirm an effort on the Deuteronomic side to give a unique structure to the list it has in common with the Levitical text. This does not however imply that the text in Deuteronomy was based on the Levitical text. Morran (1966:277) concluded in his study that an original list of only 10 unclean birds, was used in the Deuteronomy text, while a further ten names "were borrowed directly from the parallel passage in Lv 11." The implication of this theory is that the Levitical text is supposed to be older than the Deuteronomy text - a theory which is not sustainable. The viewpoint of Eilberg-Schwartz (1990:219), on the other hand, is that "Leviticus 11 reworked Deuteronomy 14 in such a way as to bring it into closer correspondence to the creation story." This viewpoint presupposes that Deuteronomy is the older text and that the creation story served as model for the Levitical thinking. This depends on a specific theory of Pentateuchal growth which we shall deal with later on.

Morrow's study (1995:66) of "clause rows" in Deuteronomy 14:1-17:13 also compared the parallels between Deuteronomy 14:4-8 and Leviticus 11:2b-8, Deuteronomy 14:9-10 and Leviticus 11:9-12. He observed “... that Lev 11:2-8 and Deuteronomy 14:4-8 are both expansionary with respect to each other. As the expansions are not found in the same place, it is best to conclude that Lev 11:2-8 and Deuteronomy [14:]4-21a $\alpha$ represent independent recensions of a common tradition" (Morrow 1995:74-5). The Deuteronomic text is not dependent on the parallel text in Leviticus 11. The cohesion of the Deuteronomy text excludes this possibility. He cannot agree with Merendino that Deuteronomy 14:4-20 has a core of fauna and accompanying commands in 4-5, 12b-18 and $19 \mathrm{~b}$ around which the rest of the material has accumulated in two discernable stages of composition. Neither can he subscribe to Bettenzoli's theory of a core found in 4-6, and 9, because no attention was given to the detail of "clause row cohesion" (cf Morrow 1995:197). Although he acknowledges Dion's theory of a four stage formation of Deuteronomy and ascribes Deuteronomy 4:4-20 to the first stage of "pre-deuteronomic sources", his study of clause rows and cohesion in its present literary units, prevented Morrow from making allowance for pre-stages of Deuteronomy 14:4-20. When he allows for further developments in the formation of Deuteronomy, he should allow for previous developments as well. 
According to Von Rad (1966:102) the Deuteronomic writer employed catalogues which "were no doubt drawn up by the priests at the sanctuaries". Both Deuteronomy and Leviticus "seem to go back to one and the same list" (Von Rad 1966:102). Given the differences between the lists of water and air animals indicated above, and the agreement in structure and motivational clauses in the category of land animals (Dt 4:4-8; Lv 11:2b) it is probable that the oldest form of the three part list, found in Deuteronomy and Leviticus, comprised the section of land animals. If there had been a common list, it would rather have been a list of land animals, which was expanded upon by both with a list of water and air animals, but doing so in different ways. Morrow saw Deuteronomy 14:4-8 and Leviticus 11:2-8 as expansionary with respect to each other (cf above Morrow 1995:74). Each list, together with its distinct extensions, was compiled on the ground of mutual socio economic, but also distinguishable ideological considerations so as to formulate a specific theological view held on dietary customs.

As human institutions and ideas are the direct result of material circumstances, so too can dietary regulations be seen as the consequence of economic and ecological circumstances. General conditions in the Near East caused cud chewing animals (regarded as clean in Israel) to be best suited as a food source from an economic point of view. They could feed on grass and other plant foods, for which humans have no use. By converting grass and plant food into meat supply, they provided a food source which, in economic terms, provided an ideal return. For the same kind of environmental and economic reasons, unclean animals, like the pig, were prohibited as food. Pastoral nomads could not herd these animals over long distances and in arid grasslands. They could not live on grass and could not swim across rivers. They could only be raised by being fed on grain - which made them economically costly for the community and made them direct competitors with humans for food. The list of clean and unclean animals therefore reflects the codifier's attempt to prove a special knowledge of the natural and supernatural worlds.

Food taboos however do not arise from ecological conditions only. Codifiers of lists of clean and unclean animals differed in their knowledge and views of the world (cf Mayes 1994:171-172). Douglas and Soler indicated the close relationship between the dietary regulations and the Israelite understanding of creation. Clean animals are those 
conforming to the plan of creation. They are herbivorous and clearly belong to an appropriate element in creation: earth, sky or water. Unclean animals are those that transgress these boundaries, particularly through exhibiting means of locomotion which make them suited to more than one element. Knowledge of these boundaries, and views on what the plan of creation is, differed between groups. According to Mary Douglas the social function of dietary regulations could mark out one group from another. It could also serve the internal self understanding of a group. The differences between the Deuteronomic list and the Levitical collection indicate a difference of views on the world and of the communities, presupposed by the dietary regulations of each. It could even indicate a difference between the community presupposed by the dietary regulations of Deuteronomy 14 and the rest of Deuteronomy (cf Mayes 1994:179).

Within the same general social context, different religious groups, not necessarily from the same time or place, each had their own ideas on food and the religious meaning thereof. The unique view represented by the Deuteronomic dietary laws was expressed by the peculiar way in which the original list of land animals was extended and structured, using numbers such as 7 and creating specific patterns where prohibition and consent alternate with one another. This could have formed a second, or at least one of the earliest layers, of the list of dietary regulations in Deuteronomy.

\section{THE STRUCTURE OF DEUTERONOMY 14:3-21c}

\begin{tabular}{|c|c|}
\hline \multicolumn{2}{|l|}{ DEUTERONOMY 14:3-21a } \\
\hline 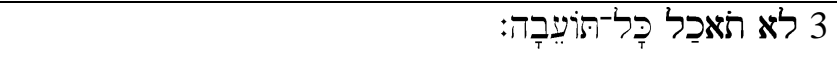 & Heading: Prohibition (position A) \\
\hline 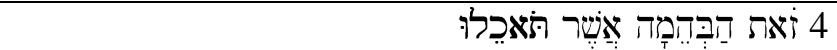 & [Chiasmus] \\
\hline & Consent (position B) \\
\hline & [ANIMALS ON LAND] \\
\hline 20 כּל־עוֹך טָהוֹר תאכֵלוּ: & Consent (position B) \\
\hline 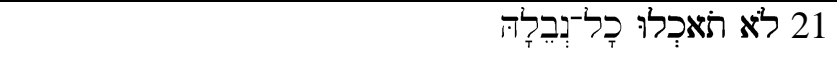 & [Chiasmus] \\
\hline & Prohibition (position A) \\
\hline & [DEAD ANIMALS] \\
\hline
\end{tabular}


A study of the structure of Deuteronomy 14:3-21a(-c) not only reveals additions to the layer respresented in 14:4-20, but also reveals the tendency to frame probably older sections and to put them in an inclusio. A heading is added to the list in verse 3 to

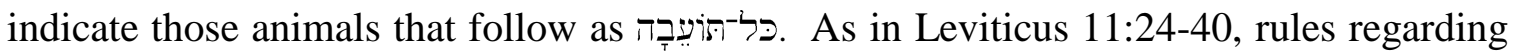
animals who are dead, are also annexed to the dietary rules in Deuteronomy 14:21a-c. Where the Levitical regulations however merely prohibit the touching of these animal carcasses because they are unclean, Deuteronomy 14:21 explicitly prohibits the eating of meat from such carcasses. This addition does not introduce a new section, but forms an extension of the former list.

Moreover, these additions form a chiasmus at both the beginning and the end of the earlier list in Deuteronomy. The order of verse 3, prohibiting the eating of anything which is is is not only inverted in the order of the sentence in verse 4, but a word of consent is also given against the word of prohibition in verse 3. The same happens between the end of the probable older Vorlage in verse 20 and the next "new" sentence in verse 20a. Consent in the final position in verse 20 is followed by prohibition, which stands in the first position of verse 21. These two chiasmi form a frame for the section of dietary laws in Deuteronomy 14:4-20. It is an indication of a later layer in the literary growth of the dietary regulations in Deuteronomy.

We find here a process of framing or contextualising older material by inserting it into a frame. In this way, new or additional meaning is given to the older material. Each phase of recontextualising or framing forms a new heuristic frame of reference for understanding these older rules and the religious and ethical implications thereof within a new context. The use of the term in visu 3 places these dietary rules in the frame of cultic purity. Not only are dead animals not to be touched (like in Leviticus), but they are also regarded as carrion, which is detestable and the eating of which is totally prohibited. The set of dietary regulations in the form of a list of clean and unclean animals, are recodified to function within a cultic frame of human pureness.

\section{THE STRUCTURE OF DEUTERONOMY 14:1-21}

The next step in the literary history was to link 14:3-21c to 14:1-2 and to 14:d. The technique of inclusio was again used. The older section was recontextualised and put in a 
frame which gave new meaning to the existing list of dietary regulations. A double

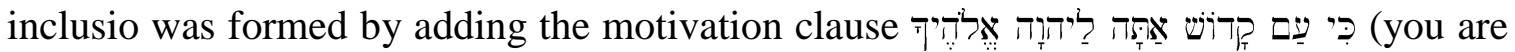
a holy people to the Lord your God) in verses $2 \mathrm{a}$ and $21 \mathrm{~d}$. The motivation of a holy people put the dietary rules in a theological frame connected to the status of the Israelites as God's unique people. Cultic purity in terms of what is eaten and what is abstained from, marked Israel as the holy people of God. The second member of the inclusio is found in the reference to a dead person (מת) in verse 1c, corresponding with a dead body (ניבלָה) in verse 21a. The mourning customs prohibited in verses 1 and 2, are the rituals followed by other nations "for the dead" (14:1c). Along with the dead animal in verse 21a-c, the sphere of life and death is indicated, which is the specific area of ancient Near Eastern fertility cults and ancient Oriental otherwordly religions. Transgression of the dietary rules implied that Israel entered the sphere of forbidden cultic heathen practices, something which is totally irreconcilable with being God's holy people. Being holy for Yahweh means the avoidance of the death rituals of other nations and, via the prohibition to eat carrion (cf Braulik 1993:324), to abstain from eating any animal which is classified as "unclean".

Probably another frame is to be found in verse 1a and 21e. The correlation between "children of God" in verse 1 and the prohibition of cooking a young goat in its mother's milk in verse 21e is quite problematic (cf Labuschagne 1990:60). It can be linked using the concept of being the child of a parent: God's children linked to the child of the mother goat (cf Braulik 1993:324). Another possibility is to use the blood motif which runs like a golden thread ("rode draad") through the passage of verses 1-21 (Labuschagne 1990:60). The slaughtering of animals ritually links to “... das Verbot des Blutgenusses in Deuteronomy 12, 23f." (Otto 2000:256). This outer frame would then be a technique used by the Deuteronomic redactor to link the dietary regulations presented in a framework of holiness to God, achieved by abstaining from fertility cults, to the rest of his composition, especially to the cultic regulations in Deuteronomy 12:20-28. 


\begin{tabular}{|c|c|}
\hline \multicolumn{2}{|c|}{ DEUTERONOMY 14:1-23 } \\
\hline 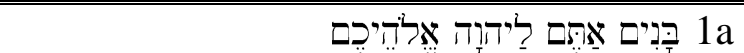 & Children/blood \\
\hline 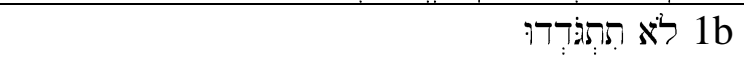 & \\
\hline 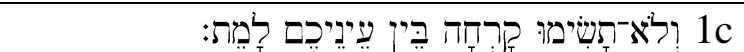 & Dead person \\
\hline 2a & Motivation Clause. \\
\hline 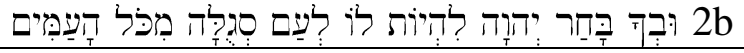 & \\
\hline 2c $2 \mathrm{c}$ & \\
\hline 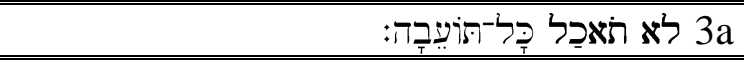 & Chiasmus with $4 a$ \\
\hline 4a & Chiasmus \\
\hline 20 כָּל־עוֹף טָהוֹר תאכֵלוּ: & Chiasmus with $21 a$ \\
\hline 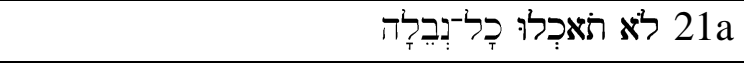 & Dead Body \\
\hline 21b $21 \mathrm{~b}$ & \\
\hline 21c & \\
\hline 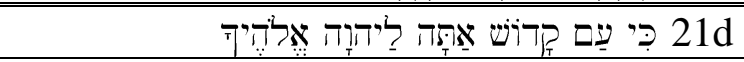 & Motivation Clause \\
\hline 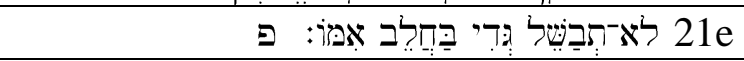 & Children / Blood \\
\hline
\end{tabular}

No clear indication can be found as to when these different layers were added. If it is supposed that Josiah used a document found in the temple and that it was the Deuteronomic Code (Deuteronomy 12-16), or parts thereof, then the addition of these different layers could already have been completed. It is in any event clear that we are dealing with a multilayered literary unit in Deuteronomy 14:1-21. There are clear indications of a process of growth in the present literary structure. As time progressed, a contextualising process took place, which changed the actual meaning of the dietary rules. Each new frame gave a new heuristic context to a growing collection of dietary rules. In its present state, we are dealing with a “... zeer zorgvuldig deurdachte compositie ... die even zorgvuldig van een kader is voorsien (vss 1-3 en 21), zodat vss. 121 een literaire eenheid vormen" (Labuschagne 1990:60). We are thus dealing with a literary unit, where a well structured exemplary set of dietary regulations was set in a cultic context and then recontextualised in a frame of holy people, who are to be sanctified to the Lord by not only avoiding heathen cults and customs, but also by being discriminatory in which meat they eat. 
It can be graphically summarized as follows:

\begin{tabular}{|c|c|}
\hline & Oldest Vorlage -land animals \\
\hline $\begin{array}{l}\text { Cosmic view of land, sea and air } \\
>\end{array}$ & $\begin{array}{l}\text { Next phase } \\
\text { - addition water and air animals }\end{array}$ \\
\hline 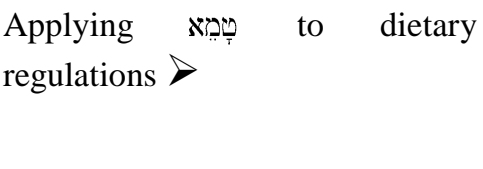 & $\begin{array}{l}\text { Chiastic Frame }- \\
\text { heading (verse } 3)+ \text { prohibition to } \\
\text { eat dead animals } \\
(\text { verse } 21 \mathrm{a}-\mathrm{c})\end{array}$ \\
\hline $\begin{array}{l}\text { Holy people }> \\
\text { Cult of life and death }>\end{array}$ & $\begin{array}{l}\text { Double inclusio - } \\
\text { holy people motivation (verses } 2 \text { a } \\
\& 21 \mathrm{~d} \text { ) } \\
+ \text { dead person, dead meat (verses } \\
1 \mathrm{c} \& 21 \mathrm{a}-\mathrm{c}\end{array}$ \\
\hline \multirow[t]{2}{*}{ Children/ blood motif } & Overall frame in $14: 1$ and $21 \mathrm{e}$ \\
\hline & Inclusion in Deuteronomic Code \\
\hline
\end{tabular}

\section{THE DEUTERONOMIC CODE (DT 12-26)}

\subsection{A theoretical framework}

When it comes to explaining the position of Deuteronomy 14:1-21 within the Deuteronomic Code, the whole issue regarding the growth of the Pentateuch comes into play. Finding the place of the dietary laws in Deuteronomy calls for more than a literary structural analysis on the synchronic level. As there is no direct relationship to either the preceding or the following sections of the book, redactional theories on a diachronic level are required to try and explain the meaning of these regulations within their larger context. As we have to deal with hypotheses on the growth of Deuteronomy and the Pentateuch, different opinions will have to be considered. Consequently, different theories will now be summarised and used to indicate the probable place(s) of these dietary regulations within the larger literary context.

Evaluating these different theories, Mayes' (1994) view on the formation of theories should be kept in mind. He referred to McBride, who sees in the laws of Deuteronomy real demands constituting a divinely authorized social order which Israel had to implement to secure its collective political existence as the people of God. Mayes also referred to the opposite opinion of Noth and Von Rad that Deuteronomy's inde- 
pendence from the state and its legal requirements is maintained at all times. According to Mayes' conclusion, both positions have validity, as both directions offer interpretations which stand in line with tradition, reaching back to the Old Testament itself "and it is from that tradition that the anticipation of meaning which leads eventually to this interpretation has been taken." (Mayes 1994:169). In our case it is to be expected that the "anticipation of meaning" would be attached to the technique of contexualising we found in the literary history of Deuteronomy 14:1-21. Something of this recontextualising is to be expected in the different theories on Deuteronomy. Old Testament science is, after all, the game of designing heuristical contexts as a frame of reference to help us understand an ancient book, quite removed from our own time and space.

\subsection{The dietary regulations are not originally part of the Deuteronomic Code}

Miller (1990:129-130) links Deuteronomy 12:1-32 to chapters 13 and 14:22-29. The concern of resistance to the allure of the Canaanite gods and worship practices is continued in chapter 13, in which rules are given for guarding against such practices "and safeguarding the maintenance of the first and second commandments. Chapter 14:22-29 continues the regulation of sacrifice and worship, but does so in terms of tithing" (Miller 1990:130). What is remarkable though, is that Miller does not include Deuteronomy 14:1-21 in this frame, nor does he treat the laws in his commentary on Deuteronomy.

Mayes (1994:181) explicitly denies that the dietary regulations of Deuteronomy 14 form part of the deuteronomic law code. The perception of Israel in its relationship with Yahweh in Deuteronomy 14 is different from that which is found elsewhere in the book. The dietary regulations found in here are "... a post-exilic priestly insertion in the deuteronomic law, made with the aim of bringing to expression a much more rigidly clear understanding of the nature of Israel than the deuteronomic law had envisaged" (Mayes 1994:181).

Miller confirms the problem of finding a place for the dietary rules in Deuteronomy 14:1-21 within the larger context of Deuteronomy. Mayes' investigation treats them as some kind of addendum from a later time, which does not fit the original pattern of the book as he sees it. This still leaves us with the question of why this passage 
was added exactly in this place and to establish for whom it made sense to include it in Deuteronomy, and not somewhere else.

\subsection{Fitting the dietary regulations into a pattern found elsewhere in Deu- teronomy}

\subsubsection{G Braulik}

Braulik closely links the covenant and the Decalogue. The Decalogue is the

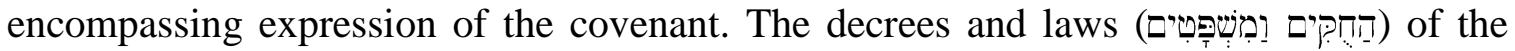
covenant are not only found in the Decalogue in Deuteronomy 5, but also in the law code in Deuteronomy 12:1-26:16. The Decalogue is not only explicated in the law code of Deuteronomy 12-26, but it also served as "Strukturmuster der deuteronomischen Gesetzessamlung” (Braulik 1991:21). Although different principles were used in combining different original independent laws in a previous stage, in the final redaction the Decalogue can be seen as “... Grobraster für Komposition und Disposition des Gesetzescodex" (Braulik 1991:22), and as the "structural principle" (Braulik 1993:317). It is a "systematisation at the level of final redaction" (Braulik 1993:320). The individual laws are commentary and concretizations of the Decalogue (Braulik 1993:334).

The correspondence between Deuteronomy 12-18 and the first four commandments (according to the Roman Catholic demarcation of the Decalogue) is more "global" than in Deuteronomy 19-25, where there is closer relevance to the last six commandments of the Decalogue. It corresponds to the Decalogue "only in some rather vague and general respects" (Braulik 1993:321). Deuteronomy 14:1-21 corresponds to the second commandment forbidding using the name of the Lord in vain. Like 13:1-8, Deuteronomy 14:1-21 is also connected to $12: 31$. The grouping of laws in chapter 12 according to the place chosen by Yahweh, is followed in 13:1-14:21 with “... a kind of associative digression" (Braulik 1993:325).

Braulik (1991:35) acknowledges that this treatment of Deuteronomy 14:1-21 can only relate to the commandment on the Lord's name in Deuteronomy by deduction (einige Denkumwege) (“a very roundabout process of reasoning” (Braulik 1993:327). It is even possible as far as redactional criticism is concerned, that no original connection of chapter 12-16 with the first three commandments of the Decalogue might have been 
intended (cf Braulik 1993:327). Nevertheless, Braulik is of the opinion that a later relecture, which worked with the idea of a Decalogue codex, could have included the unit in the conceptual structure that organized the whole codex, understanding it to bemisuse of the name of the Lord when Israel forlorned their unique identity by following the wrong rituals of other nations.

\subsubsection{W S Morrow}

Morrow's study (1995:66) of "clause rows" in Deuteronomy 14:1-17:13, already referred to, follows Dion's proposal for four main stages in the formation of Deuteronomy:

- $\quad$ pre-deuteronomic sources;

- the contribution of those Deuteronomic writers who put together the book of the law found in $622 \mathrm{BCE}$;

- a pre-exilic Deuteronomistic layer to be assigned to the time of Josiah;

- exilic Deuteronomistic additions.

Many pre-Deuteronomic traditions from stage 1 were included in the redaction in stage 2 during Josianic times. Stage 2 is called the פip-sequence (Morrow 1995:13) "because its primary concern is with actions and journeys connected to the "place which Yahweh your God chooses". "Nevertheless, it is evident that the mqwm sequence is composed as a commentary on 12:13-19 and that its organisation is not dependent on a single, preexisting text or tradition" (Morrow 1995:13). The redactional activity of Josianic redaction (no 3 ) is not clear. Literary activity subsequent to the "maqwm sequence" (no 4) belongs to the time of the exile and later (cf Morrow 1995:223).

The secondary redactions of the themselves with describing the nature of that society which organizes itself around the place which God chose. They are particularly interested in promoting cultural solidarity and distinctiveness (cf Morrow 1995:14). This group includes among others Deuteronomy 14:1-21. Sections like Deuteronomy 14:1-21, 15:4-6,7-18 and 16:21-17:7 were supple-mented in the typical way of ancient legal texts at the beginning or end of an existing section of relevant material. As Deuteronomy 14:22-27 deals with the 
where food should be eaten, Deuteronomy 14:1-21 was inserted right here. Deuteronomy 14:1-21 can be regarded as a construction whose concern for separateness, fits in between anti-idolatry polemic in Deuteronomy 13 and the following concern for food offerings in 14:22-27. "The concern of 14:3-21 is that the chosen people maintain their holiness by strict observance of food laws." But Deuteronomy 14:1-21 also develops the concerns of the framework linking Deuteronomy 12 and 13. Since idolatry is associated with death, the concern to avoid death, frames Deuteronomy 14, as it occurs in 14:1, 21a. "With prohibitions which touch on both food preparation and illegitimate cultic rites, 14:1-21 acts as a transitional section between Deuteronomy 13 and 14:22-27" (Morrow 1995:26).

Braulik represents the final form of Deuteronomy. He does not indicate the previous stages of the literary history on which the final stage was based. His theory does not give any real rationale for the inclusion of dietary regulations at this specific location in Deuteronomy. Morrow describes the earlier stages without giving an indication of the final framework. Deuteronomy 14:1-21 is a mere transitional section, linking cult and food without explaining where it fits into the framework of God's chosen place. A more comprehensive theory, which encompasses the later and final literary history as well, is needed.

\subsection{Eckart Otto's theory}

Otto reads Deuteronomy 14 against the background of a long redactional history. According to his theory, the oldest sections of the eventual Deuteronomy 12-26 originated during the seventh century BCE. During this time a reform program was launched to reformulate middle Assyrian law codes. In the same way, a reform program was launched in Israel. Family laws, as well as laws forming a Book of the Covenant, were collected. Parallel to this, the earliest Deuteronomic redaction used Asarhaddon's "adê" (Loyalitätseid) from the year 672 BCE as pattern to formulate a "Treueid" (oath of loyalty) to Jahweh. In this reformulation, undertaken somewhere between 672 and 612 BCE (during Josiah's reign), the Assyrian oath was "subversiv rezipiert" (Otto 1999:14) and used to demand sole loyalty to the God of Israel. This "recycled" Assyrian "adê" and its stipulations were used to form the contents of Deuteronomy 13:2-10* and 28:20$44^{*}$. To Deuteronomy 13:2-10* were added the rules of Deuteronomy 17:2-7*. 
The main purpose of the then existing form of Deuteronomy however was centralisation of the cult. Fixing the laws to either the local or the central seat of judgment, formed the backbone of the reform program ("das Rückgrat der vorexilisch-dtn Redaktion des Deuteronomium" Otto 1999:218). A "Modelprozeß mit Zweizeugenregelung" was developed for the demarcation of the jurisdiction of the regional law court and the central jurisdiction as it is presented in Deuteronomy 17:8-13*" (Otto 1999:217). All cases of religious-political nature fell under the jurisdiction of the regional court

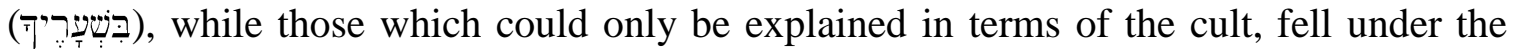

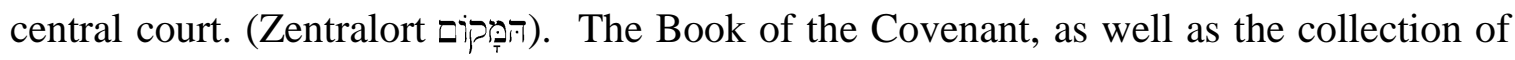
family laws were also reworked according to this theme of centralisation. All of this formed part of the pre-exilic redaction of Deuteronomy, the "vorexilisch-dtn Redaktion des dtn Gesetzes" (Otto 1999:217).

The symbols used by Otto for the next redactional layers are confusing. In his "Das Deuteronomium" of 1999, Otto used Deuteronomy 19 as clue to a two phase redactional reworking of the law code of Deuteronomy 12-26. In Deuteronomy 19:1, 3a, 7-9 he finds indications of a first redactional phase, which he designates here as DtrH. This redactional layer "... bindet das Gesetzkorpus an Dtn 1-3 und an die Landeroberungsüberlieferung im Buch Joshua” (Otto 1999:229). The second phase Otto (1999:229) calls DtrD, the redactional layer “die Dtn 12-26 im Horizont des Dekalogs bearbeitet".

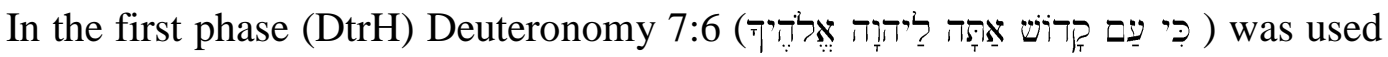
as theological guideline. Using the theme of the conquest of the land in the book of Joshua, this redactor (DtrH) took over the existing deuteronomic pattern of Deuteronomy 12-26 which had arranged the material according to main laws (Deuteronomy 12f*), lists of civil laws (Deuteronomy 14-15* and 26*), rules for festivals (Deuteronomy 16:1-17), rules for jurisdiction (Deuteronomy 16:18-18:5) and rules for materialistic order (Deuteronomy 19-25*) (Otto 1999:229). He reworked it according to the theme of the land, as it is found in Joshua. To this the war rules $\left(20: 1-20^{*}, 21: 10-14,23: 10-15,24: 5\right.$ and 25:17-19) and civil laws (23:2-9) were added. In this reworking of Deuteronomy 1226, the two aspects of internal holiness and external demarcation from other nations, were brought together. His use of the theme of the conquest of the land refers to the Persian 
era when the new Israel had to be constituted. "Integrierende Mitte des Denkens dieser Theologie ist eine Heiligkeitskonzeption, die Israel vor und nach der Landnahme, d.h. vor und nach der Beendigung des exils, nach innen als heilig konstituiert und als heiliges Volk nach außen, auch gegen die eigene verfehlte Geschichte, abgegrenzt sieht" (Otto 1999:233)

The Dekalogredaktor (DtrD) rewrote Deuteronomy 12-25 (cf Otto 1999:233) as interpretation of the Decalogue by inserting Deuteronomy 16:20-17:1. This insertion did not only provide a link to Deuteronomy 12:29-13:1, but also gave a new context to Deuteronomy 12-26. The Torah then became the criterium for a just order in Israel. Judge, priest and king are subordinated to the rule of the Torah. The priest, as executive of law and cult, is put in the central role (Otto 1999:237).

In his "Das Deuteronomium im Pentateuch und Hexateuch" (2000:237) and his overview of post priestly Pentateuch research, Otto (2002:147) uses "DtrD for the "dtr Hauptredaktion des Deuteronomiums". He transformed the late pre-exilic reform program of Deuteronomy (Dt 6:4f; 12:13-28:44*) into a Moses discourse which took place at Mount Horeb. Otto (2000:237) does not refer to this pre-exilic Deuteronomy as DtrH here, but as a redactional layer "das durch die Integration der Reformulierung des Bundesbuches in eine Loyalitätseid für JHWH durch die subversive Rezeption neuassyrischer Rechtsüberlieferung entstanden ist." The author of DtrD adds the Decalogue to his material, pointing out that the law was God's binding revelation to Moses, but the people of Israel already transgressed these laws at Horeb. He deals with the trauma of the exile and attempts to show that the Decalogue is still relevant to the exilic community. The post exilic community is synonymous with the Horeb generation and finds itself once again at the foot of Horeb. Despite Israel's violation of the first commandment and her worshipping of other gods, Yahweh continues his covenant with Israel.

The next layer Otto (2002:147) calls the "dtr Autor DtrL (2000:240) or "dtr Fortschreibung DtrL". Continuing DtrD's conflict with the aaronide program of cult foundation at Sinai in the Priesterschrift $\left(\mathrm{P}^{\mathrm{G}}\right.$ ) (cf Otto 2000:240), DtrL put the deuteronomic Deuteronomy $(5-26,28 *)$ in the frame of Deuteronomy $1-3^{*}$ and 29$30 *$ and transfers the making of the covenant at Horeb to Moab, on the other side of the 
Jordan river, before the entry into the promised land. The "dtr Josuabuch" (Otto 2002;147) deals with this history and in this way is linked to the book of Deuteronomy. In this redactional layer an indication is given of how the new Israel, the post-exilic community, can avoid a catastrophe similar to the one they had recently experienced. In this process the possession of the land became an important part of the theology of the DtrL layer. In order to retain the land, the new Israel (the post- exilic community) needed to separate itself from the pre-exilic one. By keeping the commands of Deuteronomy, a repetition of the exile could be avoided.

The ideas of DtrD and DtrL were the building blocks for the "Hexateuchredaktor (HexRed) (Otto 2002:147). The Priestly Writing ("postsinaitisch P" - Otto 2000:243) was integrated with Deuteronomy (DtrL). This redactor used Deuteronomy 1-3 as example and "spannt einen bogen von Gen 1,1 bis Ri 2,9, der seine literarischen Pfeiler in Gen 15 und Jos 24 hat" (Otto 2002:147). Linking up with the theme of DtrL, ownership of the land is the main issue in this layer. In accordance with DtrD, the covenant of Horeb and the law of Moses play a central role in such ownership.

The Pentateuch redaction (PentRed) returned to the emphasis of DtrD on Horeb and the Mosaic law (Otto 2000:245-6). The cutting of the covenant and the promulgation of the law at Sinai are made the central points of the Pentateuch. The focus is shifted towards the Torah as the main issue. To emphasize the main importance of the Torah, the Pentateuch redaction (PentRed) disconnects Deuteronomy (and the Pentateuch) from the book of Joshua and concludes this work with the death of Moses. The important role of Moses is stressed. At his death, the Torah took over and became of all importance to those in the diaspora.

Finding the place of Deuteronomy 14:1-21 among these redactional layers in Otto's work depends on which of his publications one is using: Das Deuteronomium (1999) or Deuteronomium im Pentateuch und Hexateuch (2000). The arguments for the inclusion of Deuteronomy 14:1-21 in the existing form of Deuteronomy and for the way in which it was done, are exactly the same in both publications. In the 1999 publication, however, Deuteronomy 14:1-21 is seen as the contribution of the DtrH layer. In this "nachexilischen Theologie" (see Otto 1999:230) the redactor linked a list of clean and unclean animals and prohibited practices (Dt 14:1f, 3-21a) to the main law against 
apostasy, already present in Deuteronomy 13* (Otto 1999:230). "Diese Aufzählungen haben für DtrH die Funktion, an das Verbot des Blutgenusses (Deut 12, 23f. ) anknüpfend das Volk als heilig aus der Profanität anderer Völker auszugrenzen, indem es Regeln der Beschränkung befolgt und sich von den Trauerbräuchen der Völker fernhält" (Otto 1999:230). In Deuteronomium im Pentateuch und Hexateuch, this pericope is seen as the work of the successor of Dtr D, the layer DtrL:

Auf das Hauptgebot der Abwehr der Apostasie (Deuteronomy 13*) lässt der dtr Autor (DtrL) eine Liste reiner und unreiner Tiere sowie verbotener Praktiken (Deuteronomy 14,1f.3-21a) folgen. Diese Aufzählungen haben in der dtr Redaktionsperspektiv die Funktion, an das Verbot des Blutgenusses in Deuteronomy 12,23f. anknüpfend das Volk als heilig aus der Profanität anderer Völker auszugrenzen, indem es Regeln der Beschränkung befolgt und sich von den Trauerbräuchen der Völker fernhält.

(Otto 2000:256)

In both publications the arguments for the inclusion of Deuteronomy 14:1-21, even the wording of the argument, are almost identical (Otto 1999:230; 2000:2546). The theme of "holy people" is found in Deuteronomy 14:2 and repeated in 21a at the end of the pericope. Dealing with Deuteronomy 7:6, and pointing to Deuteronomy 23:15, the customs of the nations regarding mourning, and the preparation of food are rejected. Israel is a holy people, sanctified for the Lord and are not to use the same practices. Deuteronomy 14:2 quotes from Deuteronomy 7:6f. This phrase is repeated in Deuteronomy 14:21a to frame the contents of Deuteronomy 14:3-20. While the rules for the sacrifice in Deuteronomy 12:8-28 related to the central sanctuary, the cultic rules in Deuteronomy 14:3-21a are related to life in the countryside. The Leitwort unclean (טמֵא) from Deuteronomy 12:8-28 is repeated in Deuteronomy 14:1-21 "um die kultische Kategorie der Reinheit über das Zentralheiligtum hinaus auf das Alltagsleben des neuen Israel auszuweiten" (Otto 1999:231 cf Otto 2000:256). The aspect of Israel's purity, found in Deuteronomy 14:1-21, is repeated and extended in the rules of the community in 
Deuteronomy 23:2-9 and the rules for the purification of the camp in Deuteronomy 23:10-15.

According to the 1999 publication, Deuteronomy 14:1-21 should be interpreted in terms of a redactional layer (DtrH) in which the conquest of the land, internal holiness and external demarcation from other nations, were the main themes. According to the 2000 publication, it should be interpreted in terms of a DtrL layer where conflict with the aaronide program of cult foundation led to a transfer of the making of the covenant from Horeb to Moab on the other side of the Jordan river, to indicate how the post- exilic community of Israel can avoid a catastrophe similar to the one they experienced in exile.

The theory in Otto, anyway, is that the dietary rules were linked to the prohibition on blood and prevention of apostasy (external demarcation from other nations) and to advance the holiness of Israel internally. Within the context of a next layer, these dietary regulations became part of the Torah God gave to Moses at Horeb. They are relevant to the exilic community and guide Israel's conduct as God's covenant people. Within the context of the following layer, these regulations, along with the others in Deuteronomy, indicate to the new Israel of the post-exilic community how they can avoid the catastrophe of the exile and retain the land to which they returned from exile. Keeping these commandments and inter alia following these dietary rules in everyday life, would enable them to continue to live in the regained promised land. This was continued in the stages of the Hexateuch and Pentateuch redaction, where the central importance of the Torah and its regulations like the dietary rules are stressed even more.

\section{$5.5 \quad J$ Van Seters' theory}

Van Seters (1999:18) sees the literary strata in the Pentateuch as "... the product of literary activity in a few clearly identifiable stages, leaving distinct literary strata, over a period of a little more than two centuries, from the late monarchy to the late Persian periods" (Van Seters 1999:18). Preferring the supplementary or expansion model, Van Seters distinguishes three sources or literary strata within the Pentateuch: J (=non-P) and $\mathrm{P}$ in the Tetrateuch, and D (Deuteronomy). He does not accept the existence of an extensive source E. His theory is that $\mathrm{D}$ is the earliest source. $\mathrm{J}$ and $\mathrm{P}$ are not 
independent documents, but direct additions to the earliest corpus of D. The order in which the strata were formed is therefore $\mathrm{D}>\mathrm{J}>\mathrm{P}$.

The first Pentateuchal source was Deuteronomy (seventh century). During the early exilic period, this Deuteronomy was used as an introduction to a larger historical work, DtrH, which included Joshua to 2 Kings. This work was expanded in the late exilic period by a history of the people's origins (non-P or J), which covered the time from creation to the death of Moses. This historian made use of a body of traditional "fragments", some in literary form, others as popular motifs and stories , all of which he shaped and infused with his own ideological and theological concerns. The combination of $\mathrm{D}$ and $\mathrm{J}$ was then supplemented in the post-exilic period by a Priestly writer with his own distinctive traditional material and his own ideological interests (Van Seters 1999:78).

For Van Seters (1999:88) “... Deuteronomy is the key to understanding both the Pentateuch (Torah) and the historical books that follow in Joshua -2 Kings, as well as the relationship between them" (Van Seeters 1999:88). In its present form, the book is structured around the code of laws in 12-26. Josiah's book used for his reforms, was not all of Deuteronomy as we know it today, but an older nucleus, which included parts of the laws in 12-26. The narrative of Josiah's reforms in 2 Kings 23:4-24 reflects the laws of Deuteronomy 12,16:1-7, 18:1-8 and 18:9-14, and the blessing and curses of 28, as well aspart of the prologue in 6-8. The D Code (Dt 12-26) itself reflects more than one literal level. According to Van Seters (1999:194), the religious and social reform which emphasized the centralization of worship in one chosen place "... is most strongly reflected in the laws of 12:1-16.17 ..." This was the "Josianic proto-D collection". Although there are differences as to its exact extent, this first form of Deuteronomy began with the law of the central altar and the centralization of all sacrifice in chapter 12 . Annexed to it was chapter 13, in which the worship of another god was made a capital offence. Then D's concept of Israel as a chosen and holy people was related to regulations about mourning rites and to the consumption of clean and unclean animals in 14:1-21. Of importance to our survey is Van Seters' (1999:195) remark in a footnote on 14:1-21: "Some scholars regard this as a later addition, based on the P code". This section was followed by religious and ethical obligations on the tithe (14:22-29), release 
of debt and slaves (15:1-18), law of firstlings (15:19-23) and the festival calendar (16:117). Those who restrict the proto-D collection to 12:1-16:17 see the group of laws in 16:18-20:20 as a next layer. They are viewed as an ideal or utopian constitution arising from the centralization reform. The rest of the D Code (21-25), which is a mixture of civil, humanitarian and religious laws and regulations, was added to it with a minimum of Deuteronomic editing.

The next layer was a "Deuteronomistic" (dtr) reworking of the Deuteronomic material. Van Seters ascribes this and the following redactions to a redactor whom he calls "DtrH". As much of 16:18-20:20 has an utopian quality which is not reflected in any reality of the late monarchy, nor in the power of the king (17:14-20), the privileges of the Levites at the sanctuary (18:6-8), or the cities of refuge needing a large extent of land (19:1-13), it is difficult to decide whether these laws were formulated in anticipation of a reform that was never completely implemented, or whether they reflect a later exilic ideal in the event of some future restoration. Van Seters (1999:199) concludes: "What seems clear from the law code is that it represents an extended process of expansion and revision from the early, pre-D collections of law to the 'publication' of the code in connection with Josiah's reform and subsequent additions by Dtr and even by the priestly tradition." DtrH used a limited proto-Deuteronomy in 6:4-9:6*, 12-26* and 28* (with several additions) as the ideological basis for his work (Van Seters 1999:94). He framed the Deuteronomic Code with Deut 5-11* and 28*. To this he added a second frame with the prologue in $1-4^{*}$ and epilogue in $29-31^{*}$ and $34^{*}$. He added the material of Joshua to kings to the entire Deuteronomy to form a large historical work.

Different responses to the Deuteronomic reform were quite varied- the one priestly (Holiness Code) and the other lay (J) with the one preceding the other by only one or two decades (Van Seters 1999:206). The Yahweh (J) redaction took place during the Babylonian exile. J expanded the Deuteronomic history of DtrH to the patriarchs and creation to form one unified narrative. The $\mathrm{P}$ code should be seen against the background of the reconstruction of the second temple. It stands in juxtaposition to $J$ and represents a development of the ideas of the J stratum. The P stratum with its Priestly Code "is very much an ideological document that seems to elevate the priesthood of the Second Temple 
to supreme political and religious authority. It is a challenge to other forms of political leadership and other understandings of worship and theology" (Van Seters 1999:209).

In Van Seters' theory the dietary regulations were part of 12:1-16:17, the older Josianic proto-D collection. It formed part of the laws for cult centralisation, prohibiting worship of another god and advancing Israel's holiness by giving rules on mourning rites and clean and unclean animals. Within the Deuteronomistic reworking of this D Code, the dietary rules formed part of a utopian constitution primarily linked to the Josianic reforms, but eventually forming part of a larger historical work on Israel and its beliefs and customs. Within the $\mathrm{J}$ narrative the historical framework was extended to include creation and the history of the patriarchs. With the final reworking of this material by $\mathrm{P}$ the set of dietary regulations in Deuteronomy 14:1-21 found its broadest meaning along with its Levitical twin in Leviticus 11:4-24 in the context of the priesthood of the second temple with its supreme political and religious authority. It was integrated into priestly control of the everyday life of the faithful.

\section{CONCLUSION}

Several possibilities are opened up by the different theories of the Pentateuch. A key concept seems to be holiness. All through the years the dietary rules enabled the faithful to practice their dedication to God in the food they eat and that from which they abstain. By its inclusion within an ever broadening literary context, these regulations became Torah prescriptions for the way in which the covenant relationship with God could be upheld in the land to which God's people returned (see Otto). Within a society under priestly control, they became the object of contemplation on what a life of holiness means in everyday ethical terms (see Van Seters). By including or contextualising the set of dietary rules in an ever widening literary context, their meaning was applied to different sets of historical contexts enabling the faithful to live a holy life, dedicated to God, which manifested even in their culinary customs. 


\section{Works consulted}

Braulik, G 1991. Die deuteronomische Gesetze und der Dekalog: Studien zum Aufbau von Deuteronomium 12-26. Stuttgart: Katholisches Bibelwerk. (Stuttgarter Bibelstudien 145.)

Braulik, G 1993. The Sequence of the Laws in Deuetronomy 12-26 and in the Decalogue, in Christensen, D L (ed), A song of power and the power of song:essays on the book of Deuteronomy, 313-335. Winona Lake, Ind: Eisenbrauns.

Eilberg-Schwartz, H 1990. The savage in Judaism: An anthropology of Israelite religion and ancient Judaism. Bloomington, Ind: Indiana University Press.

Labushagne, C J 1990. Deuteronomium, Deel II. Nijkerk: Callenbach.

Mayes, A D H 1994. Deuteronomy 14 and the Deuteronomic world view, in Martinez, F G, Hilhorsts, A, Van Ruiten, J T A G M \& Van der Woude, A S (eds), Studies in Deuteronomy: In honour of C J Labuschagne on the occasion of his $65^{\text {th }}$ birthday, 165-181. Leiden: Brill.

Miller, P D 1990. Deuteronomy. Louisville, KT: John Knox. (Interpretation. A Bible Commentary for Teaching and Preaching.)

Moran, W 1966. The literary connection between Lv 11,13-19 and Dt 14,12-18. CBQ 28, 271-277.

Morrow, W S 1995. Scribing the center: Organization and redaction in Deuteronomy 14:1-17:13. Atlanta, GA: Scholars Press.

Otto, E 1999. Das Deuteronomium: Politische Theologie und Rechtsreform in Juda und Assyrien. Berlin: Walter de Gruyter. (Beihefte zur Zeitschrift für die alttestamentliche Wissenschaft 284.)

Otto, E 2000. Das Deuteronomium im Pentateuch und Hexateuch: Studien zur Literargeschichte von Pentateuch und Hexateuch im Lichte des Deuteronomiumrahmens. Tubingen: Mohr Siebeck.

Otto, E 2002. Forschungen zum nachpriesterlichen Pentateuch. Theologische Rundschau 67, 125-155.

Van Seters, J 1999. The Pentateuch: A social-science commentary. Sheffield: Sheffield Academic Press.

Von Rad, G 1966. Deuteronomy. London: SCM. (Old Testament Library.) 